\title{
SINGLET MOLECULAR OXYGEN PHOTOSENSITIZATION UPON TWO-PHOTON EXCITATION OF PORPHYRIN IN AQUEOUS SOLUTION
}

\author{
M. Kruk ${ }^{\mathrm{a}, \mathrm{b}}$, A. Karotki ${ }^{\mathrm{b}, \mathrm{c}}$, M. Drobizhev ${ }^{\mathrm{b}}$, and A. Rebane ${ }^{\mathrm{b}}$ \\ ${ }^{a}$ Institute of Molecular and Atomic Physics of National Academy of Sciences, F. Skaryna Ave. 70, 220070 Minsk, \\ Republic of Belarus \\ E-mail: kruk@imaph.bas-net.by \\ ${ }^{\mathrm{b}}$ Montana State University, Physics Department, Bozeman, MT-59717-3840, USA \\ ${ }^{\mathrm{c}}$ University Health Network, Ontario Cancer Institute, Department of Medical Biophysics, Toronto, ON M5G 2M9, Canada
}

Received 28 April 2005

\begin{abstract}
The high photodynamic activity of the water-soluble porphyrins is well documented. However, use of the water-soluble porphyrins as the photosensitizers in photodynamic therapy (PDT) is of limited usefulness because of the insufficient absorbance in the red wavelength region, where the tissues are transparent. The process by which these molecules can overcome these restrictions is the two-photon excitation (TPE). Up until now, this process is considered as being too inefficient and having no practical interest. In this study the two-photon absorptivity and singlet oxygen photosensitization by $5,10,15,20$-tetrakis-(4$\mathrm{N}$-methylpyridyl)-21H, 23H-porphin in aqueous solution have been examined directly. Two-photon absorption cross-section $\sigma_{\text {TPA }}$ shows the value ranging from 60 up to $180 \mathrm{GM}$ (Göppert-Mayer units), when tuning the excitation wavelength from 800 to $730 \mathrm{~nm}$. This absorbance at the blue side of the one-photon Soret band (B-band) is found to be due to two-photon allowed excitation into the state of even parity (i. e. $g \rightarrow g$ transition). TPE into Q-states is parity forbidden $(g \rightarrow u$ transitions), and $\sigma_{\mathrm{TPA}}$ does not exceed $6 \mathrm{GM}$ over $1100-1400 \mathrm{~nm}$ excitation wavelength range. TPE of porphyrin at $780 \mathrm{~nm}$ in air-saturated aqueous $\left(\mathrm{D}_{2} \mathrm{O}\right)$ solution results in efficient singlet molecular oxygen $\left({ }^{1} \Delta_{g}\right)$ photosensitization, which is detected by its ${ }^{1} \Delta_{g} \rightarrow{ }^{3} \Sigma_{g}^{-}$luminescence. Our findings prove the applicability of the TPE in photodynamic therapy and allow determining the requirements to the two-photon absorptivity of photosensitizer to be used.
\end{abstract}

Keywords: water-soluble porphyrins, two-photon absorption, photosensitization, singlet oxygen, photodynamic therapy

PACS: 42.65.-k, 33.W2

\section{Introduction}

Water-soluble cationic 5,10,15,20-tetrakis-(4-Nmethylpyridyl)-21H, 23H-porphine (Fig. 1), hereafter referred as $\mathrm{H}_{2} \mathrm{TMPyP}^{4+}$, and its metallated complexes are extensively studied during the last two decades. Interest in these compounds is called mainly due to their high photodynamic activity and capability to form complexes with proteins and DNA [1-7]. It has been noted that the photocytotoxicity of these compounds exceeds that of anionic and neutral porphyrins. In particular, $\mathrm{H}_{2} \mathrm{TMPyP}^{4+}$ is much more efficient in the induction of single- and double-strand breaks in ColE1 plasmids than anionic porphyrins, including hematoporphyrin derivatives [2]. Cationic $\mathrm{H}_{2} \mathrm{TMPyP}^{4+}$ photoinduces direct inactivation of Gram-positive $(\mathrm{G}+)$ and Gram-negative (G-) bacteria, thereby differing from neutral and anionic porphyrins that can photosensitize

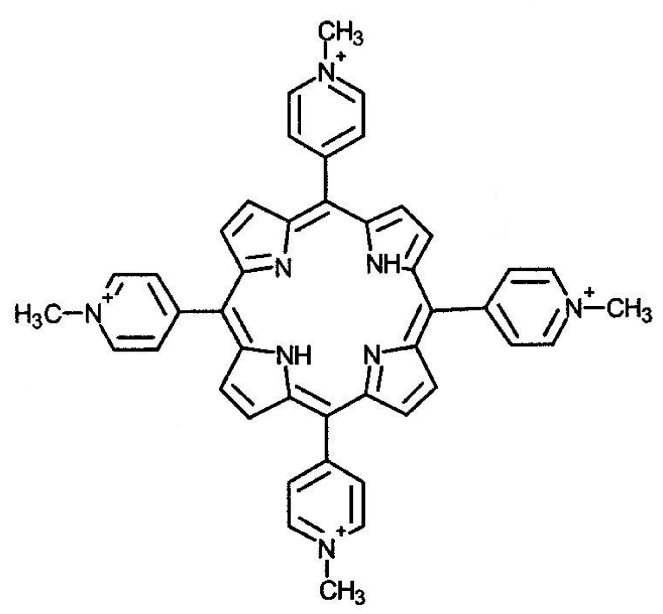

Fig. 1. Structure of $\mathrm{H}_{2} \mathrm{TMPyP}^{4+}$ porphyrin.

only after permeating the outer membrane of G- bacteria [8]. So far, the use of $\mathrm{H}_{2} \mathrm{TMPyP}^{4+}$ as a 
photosensitizer in photodynamic therapy has been limited by the fact that its lowest absorption band, centred at $638 \mathrm{~nm}$ in aqueous solution, has a small absorbance $\left(\varepsilon_{638}=1300 \mathrm{M}^{-1} \mathrm{~cm}^{-1}\right)$ [9]. Also, the above wavelength is out of tissue transparency window (750 $1000 \mathrm{~nm}$ ), which makes one-photon photoexcitation in vivo difficult [10-12].

To overcome this common for the porphyrin photosensitizers difficulty, many efforts have been made to synthesize new compounds with strong absorption band shifted to $750-850 \mathrm{~nm}[11,12]$. Alternatively, this difficulty can be overcome by means of two-photon excitation [13-15], where the excitation photon energy equals one half of the transition energy. Then the excitation light with a wavelength corresponding to the tissue transparency window can be used, thus providing for a longer penetration depth. Since the efficiency of TPA is proportional to the instantaneous radiation intensity squared [16], this effect can be dramatically enhanced by using the laser pulses of short duration. By applying modest average power in the form of one-two hundred femtosecond duration pulses, the efficiency of two-photon excitation can be brought close to that of one-photon excitation. It is evident that the peak power of the ultrashort pulses is much higher as compared to that of longer (hundreds of ps - tens of ns) laser pulses with the same energy. Nevertheless, the tissue damage threshold is higher in this case [15], thus proving the use of ultrashort pulse laser excitation in a variety of biological applications [15, 17, 18].

To be of practical interest, the photosensitizer needs to have a large probability of TPE. Early papers reported rather small $\sigma_{\mathrm{TPA}}$ values of 1-10 GöppertMeyer $\left(1 \mathrm{GM}=1 \cdot 10^{-50} \mathrm{~cm}^{4} \mathrm{~s}\right.$ per photon $)$ for tetrapyrrolic photosensitizers $[19,20]$. For this reason, it was traditionally assumed that TPA in porphyrins had a little practical value for PDT applications if any. Recently, for the porphyrin molecules the two-photon absorption cross-section amounting up to $1600 \mathrm{GM}$ has been reported by our group [21-26]. With some of these compounds we demonstrated the possibility of efficient two-photon photosensitized production of singlet molecular oxygen [21,24-26]. In these papers we have demonstrated that efficient two-photon excitation of tetrapyrrolic compounds could be achieved by using an allowed transition between the states of the same parity, i.e. $g \rightarrow g$ transition. This way of excitation turned out to be possible due to the specific energy level ordering in tetrapyrrolic compounds, possessing excited states of $g$ parity much above the first excited singlet $\mathrm{S}_{1}$-state [27].
In the experimental studies presented here we deal with water-soluble porphyrin whose photodynamic activity is well known. We report the absolute value of two-photon absorption cross-section for $\mathrm{H}_{2} \mathrm{TMPyP}^{4+}$ porphyrin in aqueous solution in different spectral regions. The measurements of the singlet molecular oxygen photosensitization have been done for solutions in heavy water with excitation by the commercial femtosecond mode-locked Ti:sapphire laser at $780 \mathrm{~nm}$. Two-photon excitation of the $\mathrm{H}_{2} \mathrm{TMPyP}^{4+}$ porphyrin results in efficient singlet molecular oxygen ${ }^{1} \Delta_{g}$ photosensitization, which is detected by means of its ${ }^{1} \Delta_{g} \rightarrow$ ${ }^{3} \Sigma_{g}^{-}$luminescence. On the basis of the obtained results we discuss the two-photon excitation scheme for PDT as well as the requirements imposed on the $\sigma_{\mathrm{TPA}}$ value of the porphyrin photosensitizer to meet PDT criteria.

\section{Materials and methods}

\subsection{Sample preparation}

The tetratosylate salt of $5,10,15,20$-tetrakis-(4-Nmethylpyridyl)-21H, 23H-porphin was purchased from Aldrich and has been used as received. We carefully examined its absorbance and fluorescence properties and found that there was no evidence of either chlorin derivative or some other impurities. Deionized $\mathrm{H}_{2} \mathrm{O}$ was obtained using standard procedure. Deuterium oxide $\mathrm{D}_{2} \mathrm{O}(99.96 \% \mathrm{D})$ was obtained from Aldrich. All measurements were carried out in rectangular $1 \times 1 \mathrm{~cm}^{2}$ quartz cells in air-equilibrated solutions at $293 \mathrm{~K}$. Electronic absorption spectra were recorded using Lambda 900 Perkin Elmer spectrophotometer. Sample concentrations were $\sim 1 \cdot 10^{-5} \mathrm{M}(=\mathrm{mol} /$ litre $)$ and have been determined spectrophotometrically using known extinction coefficients $[9,28]$.

\subsection{Instrumentation}

The laser system comprising a mode-locked Ti:sapphire laser (Coherent Mira 900) and a Ti:sapphire regenerative amplifier system (Clark MRX CPA-1000) operating at $1 \mathrm{kHz}$ repetition rate was used for excitation. The amplified pulses had duration of $150 \mathrm{fs}$ and energy of $0.8 \mathrm{~mJ}$ at $780 \mathrm{~nm}$. Tuning of the excitation wavelength was achieved with an optical parametric amplifier, OPA (TOPAS, Quantronix), which converted $780 \mathrm{~nm}$ pulses to near infrared $(1100-1600 \mathrm{~nm})$. Glass colour filters were used to cut off any residual light from the OPA. Pulse duration and temporal profile were measured with an autocorrelator. Laser spectrum 


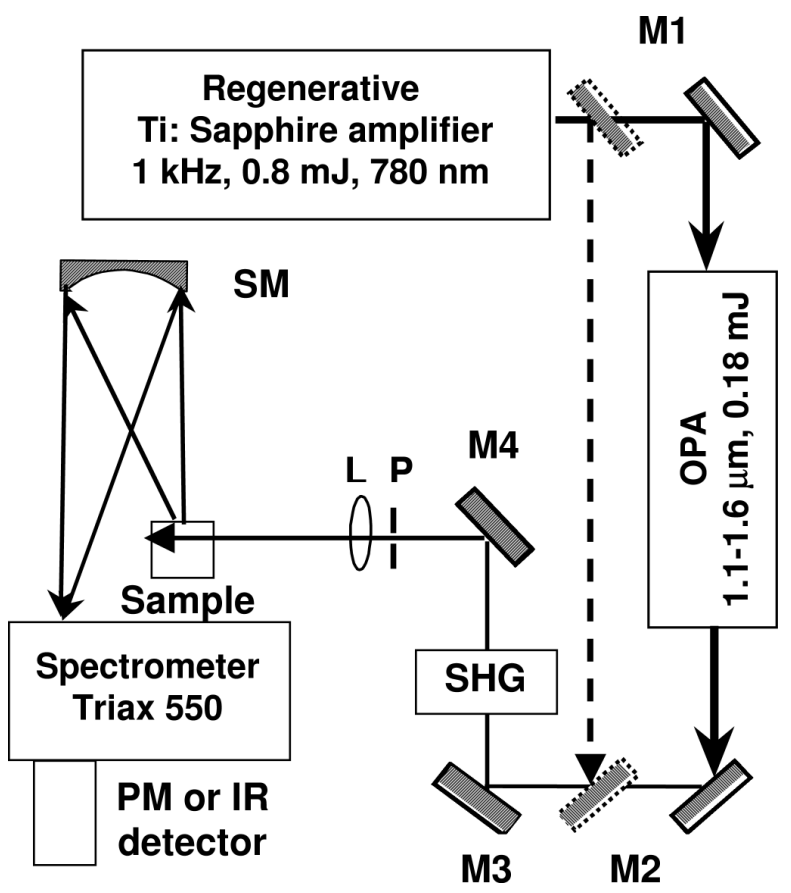

Fig. 2. Sketch of experimental setup: L is lens, $\mathrm{P}$ is pinhole, M1M4 are mirrors, SM is spherical mirror, OPA is optical parametric amplifier, SHG is nonlinear crystal for generation of the second harmonics, PM is photomultiplier.

was recorded with a Lambda 900 Perkin Elmer spectrophotometer coupled with an optical fiber, in which the laser beam was collected.

Samples were irradiated at energy in the range of 5$50 \mu \mathrm{J} /$ pulse. The laser beam was slightly focused with an $f=50 \mathrm{~cm}$ spherical lens. The focal point was out from cell, providing the $1.5 \mathrm{~mm}$ diameter of the beam in the sample cell. The pinhole with a radius much smaller than laser beam diameter was placed in front of the sample, that is why a variation in intensity over the beam cross-section could be neglected.

\subsection{TPA cross-section measurements}

TPA cross-section has been measured by a method consisting in the comparison of the sensitizer fluorescence intensity under two- and one-photon excitation $[19,24,29]$. The fluorescence emitted at a right angle to the excitation was collected by a concave mirror and focused onto entrance slit of TRIAX 550 JobinYvon/Spex monochromator (Fig. 2). The signal was measured with a Hamamatsu photomultiplier coupled with a lock-in amplifier.

The measurements were performed at $1 \mathrm{kHz}$ pulse repetition rate of the laser system. Under these conditions with two-photon excitation the fluorescence intensity was verified to depend quadratically on the illumination power. This fact means that all the possible effects due to population bottleneck and/or excited state absorption of the porphyrin should be ruled out.

The values of the TPA cross-section $\sigma_{\mathrm{TPA}}$ have been calculated according to the following formula [24]:

$$
\sigma_{\mathrm{TPA}}=\frac{\sqrt{2} \pi^{3 / 2}}{\sqrt{\ln 2}} \frac{F_{\mathrm{TPA}} \nu_{\mathrm{TPA}} \tau r_{0}^{2} E_{\mathrm{OPA}}}{F_{\mathrm{OPA}} \nu_{\mathrm{OPA}} E_{\mathrm{TPA}}^{2}} \sigma_{\mathrm{OPA}}
$$

where $F_{\mathrm{TPA}}$ and $F_{\mathrm{OPA}}$ are the fluorescence intensities upon two-photon and one-photon excitation, $\nu_{\mathrm{TPA}}$ and $\nu_{\mathrm{OPA}}$ are the frequencies of the two-photon and onephoton excitation light, $\tau$ is a pulse duration (FWHM), $r_{0}$ is the laser beam (pinhole) radius, $E_{\mathrm{OPA}}$ and $E_{\mathrm{TPA}}$ are the energies of laser pulse used for one- and twophoton excitation, and $\sigma_{\mathrm{OPA}}$ is the linear one-photon absorption cross-section at the frequency $\nu_{\mathrm{OPA}}$.

\subsection{Singlet oxygen luminescence measurements}

Steady-state spectra of ${ }^{1} \Delta_{g} \rightarrow{ }^{3} \Sigma_{g}^{-}$molecular oxygen luminescence were measured with a liquid nitrogen-cooled Ge-detector coupled with a lock-in amplifier and TRIAX 550 Jobin-Yvon/Spex monochromator. The sample concentration, position of the cell, as well as the laser pulse duration and power were exactly the same as in the case of TPA cross-section measurements, thus providing the same way of porphyrin photoexcitation, i.e. we only replaced the photomultiplier tube by IR-detector to detect the ${ }^{1} \Delta_{g} \rightarrow{ }^{3} \Sigma_{g}^{-}$luminescence of molecular oxygen. Singlet oxygen formation is due to the energy transfer from photoexcited porphyrin molecule. Thus, if the photosensitizer is excited in a two-photon process, the photosensitization has the same law. To facilitate the singlet oxygen luminescence detection, $\mathrm{D}_{2} \mathrm{O}$ was used as a solvent instead of $\mathrm{H}_{2} \mathrm{O}$ because in the former case singlet oxygen possesses much longer ${ }^{1} \Delta_{g}$ lifetime [30]. The dissolved oxygen concentration in both $\mathrm{D}_{2} \mathrm{O}$ and $\mathrm{H}_{2} \mathrm{O}$ is the same $\left(2.8 \cdot 10^{-4} \mathrm{M}\right)$.

A number of control experiments have also been performed. Specifically, singlet oxygen signals were not observed under the same excitation conditions neither upon porphyrin sample bubbling with nitrogen (leading to decrease in dissolved oxygen concentration), nor from free $\mathrm{D}_{2} \mathrm{O}$. We were also unable to reveal ${ }^{1} \Delta_{g} \rightarrow$ ${ }^{3} \Sigma_{g}^{-}$luminescence from porphyrin solution of the same concentration prepared in $\mathrm{H}_{2} \mathrm{O}$, because in such a case its intensity was much lower, and sensitivity of our instrument was not sufficient to detect it. 


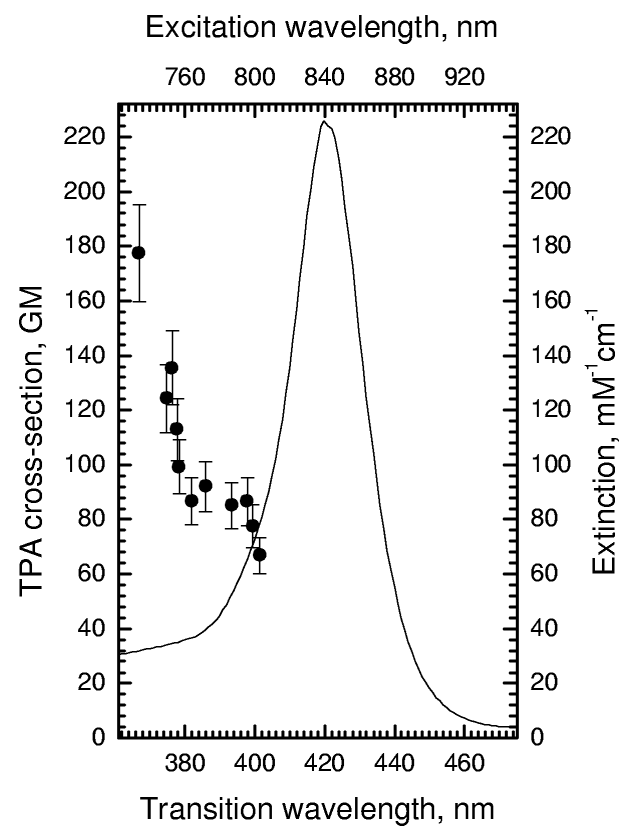

(a)

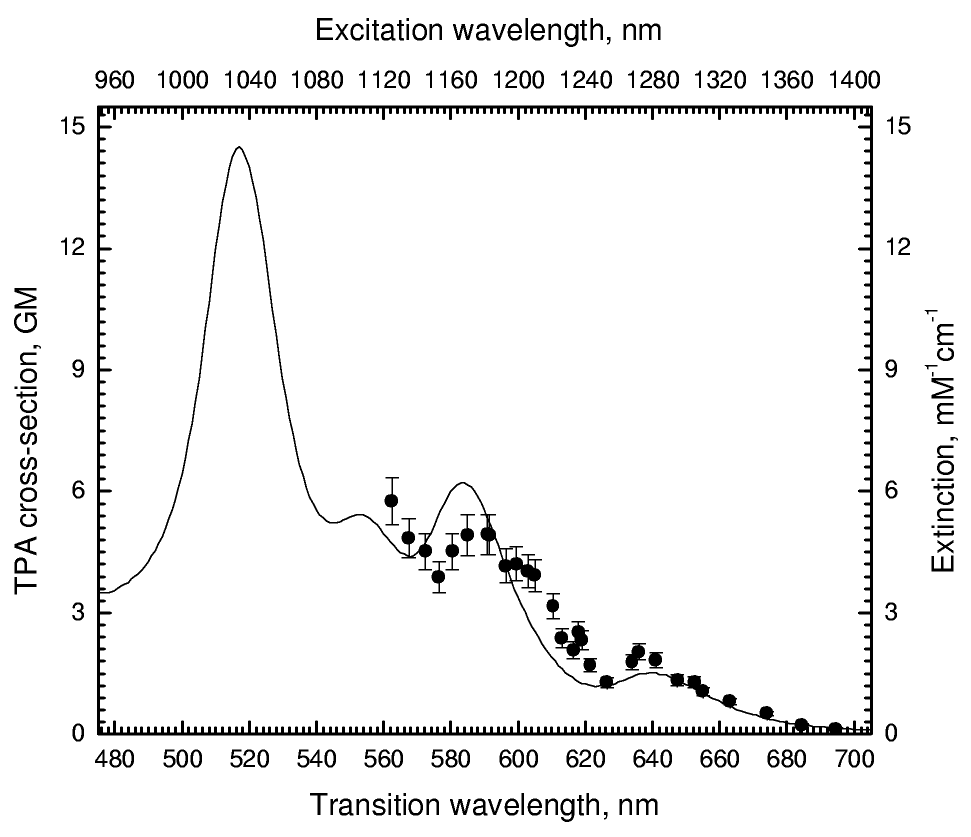

(b)

Fig. 3. $\mathrm{H}_{2} \mathrm{TMPyP}^{4+}$ porphyrin two-photon absorption spectra (closed circles and left scale) in (a) Soret band and (b) Q-band regions. Solid line is the corresponding linear absorption spectrum (right scale).

\section{Results and discussion}

\subsection{Two-photon absorption spectra and cross-sections}

Figure 3 represents one- and two-photon absorption spectra of $\mathrm{H}_{2} \mathrm{TMPyP}^{4+}$ in aqueous solution measured in the region of (a) Soret and (b) Q-bands. In the short wavelength region the linear (i. e. one-photon) spectrum of $\mathrm{H}_{2} \mathrm{TMPyP}^{4+}$ has strong Soret band with maximum at $422 \mathrm{~nm}$ (Fig. 3(a)). In the long wavelength region the linear spectrum is of phyllo-type and consists of four bands centred at $638,583,552$, and $516 \mathrm{~nm}$ (Fig. 3(b)). No changes in the spectrum have been found when changing solvent from $\mathrm{H}_{2} \mathrm{O}$ to $\mathrm{D}_{2} \mathrm{O}$. All these features are in good agreement with the published data $[9,28,31]$. We ascertained that for the samples used in two-photon experiments, the absorbance in the wavelength range 730-1400 $\mathrm{nm}$ did not exceed 0.001 .

In the visible region the measured TPA bands practically coincide in energy with those of linear spectrum (Fig. 3(b)). The TPA cross-section has moderate values and does not exceed $6 \mathrm{GM}$ over the whole $\mathrm{Q}$ band range studied (i. e. $560-700 \mathrm{~nm}$ and $1120-1400 \mathrm{~nm}$ for the transition and excitation wavelengths, respectively). Comparison of the two-photon absorption spectrum pattern with the corresponding one-photon one indicates that two-photon transition into vibronic $\mathrm{Q}_{x}(0,1)$ state is enhanced in contrast to that into the pure electronic $\mathrm{Q}_{x}(0,0)$ state. This behaviour is explained by the symmetry considerations. Assuming $\mathrm{H}_{2} \mathrm{TMPyP}^{4+}$ has a centre of inversion, two-photon transition into pure electronic $\mathrm{Q}_{x}(0,0)$ state (it is of $u$ parity) will be parity forbidden since the ground state is of $g$ parity. Prohibition is lifted because of the molecular symmetry distortions originating mainly from interactions between the porphyrin macrocycle and the four methylpyridyl substituents in the meso positions. Dihedral angle $\Theta$ between the mean porphyrin plane and the plane of pyridyl ring is about $65^{\circ}$ [32]. Thus, the observation of the TPA transition into $\mathrm{Q}_{x}(0,0)$ state in $\mathrm{H}_{2} \mathrm{TMPyP}^{4+}$ indicates that its symmetry is actually lower than $\mathrm{D}_{2 h}$, which is usually attributed to symmetrically substituted free base porphyrins. The increase of TPA in vibronic band is due to the coupling between electronic and vibrational wavefunctions [24]. The parity of the vibronic wavefunction results from parities of electronic and vibrational wavefunctions. Since, for the first excited $\mathrm{Q}_{x}(0,0)$ state, the electronic moiety is of $u$ parity, its combination with $u$ parity vibrational wavefunction leads to overall $g$ parity state: $\phi_{u} \chi_{u}=\Phi_{g}$. Therefore, two-photon transition into the vibronic $\mathrm{Q}_{x}(0,1)$ state should be considered as an allowed one [24].

In UV region (360-400 nm) the $\sigma_{\text {TPA }}$ value has been measured to be as high as 60-180 GM (Fig. 3(a)). We should stress that this band in TPA spectrum does not coincide with the Soret band and has no counterpart at all in one-photon spectrum, which consists of a series of $g \rightarrow u$ transitions. Nearly monotonic increase of $\sigma_{\text {TPA }}$ towards higher frequency as well as rather high 
cross-section values can be explained by the presence of allowed two-photon $g \rightarrow g$ transitions, which are predicted to lie near or above the B state [27]. Thus, the measured TPA spectrum can be attributed to several overlapping $g \rightarrow g$ transitions, giving rise to a broad TPA absorption band. For all the wavelengths we attested that the two-photon excited fluorescence does have a quadratic dependence on laser power. At lower excitation wavelength, this dependence gradually transforms into linear one because of the onset of one-photon absorption. This experimental circumstance prevents the extension of spectral range of TPA measurements deeper into UV where the maximum of this new TPA band should lie. The effect of resonance enhancement can also contribute to TPA cross-section growth, since the frequency of the excitation photons is close to the frequency of the one-photon allowed Q-transition [22]. More detailed analysis of the TPA spectra features for 15 porphyrin molecules including several tetra-aryl-substituted derivatives has been reported in our recently published paper [24].

There is some controversy in the values of quantum yield of the singlet oxygen photosensitization $\Phi_{\Delta}$ by $\mathrm{H}_{2} \mathrm{TMPyP}^{4+}$ porphyrin, and we want to clear up the situation before discussing the experimental results in this field. Several values of $\Phi_{\Delta}$ for $\mathrm{H}_{2} \mathrm{TMPyP}^{4+}$ porphyrin were obtained so far, varying from 0.58 [33] to 0.9 [6]. The last value measured by Kruk et al. [6] seems to be overestimated because the authors have relied on an overestimated $\left(\Phi_{\Delta}=0.70\right)$ value for $\mathrm{H}_{2} \mathrm{TSPP}^{4-}$ [34], which they have used as a reference compound. Recent report by Braslavsky's group clearly indicates that the latter value has to be corrected to $0.62 \pm 0.03$ [33]. Taking this into account, the value for $\mathrm{H}_{2} \mathrm{TMPyP}^{4+}$ reported in Ref. [6] should be replaced by 0.77 , which is close to 0.74 reported by Verlhac et al. [3]. The quantum yield of the singlet oxygen photosensitization $\Phi_{\Delta}$ by $\mathrm{H}_{2} \mathrm{TMPyP}^{4+}$ porphyrin averaged over all the reported values in Refs. $[3,6,33,35]$ is 0.71 .

\subsection{Singlet oxygen photosensitization upon TPE of porphyrin and its implications for PDT}

Figure 4 shows the ${ }^{1} \Delta_{g} \rightarrow{ }^{3} \Sigma_{g}^{-}$luminescence spectra of molecular oxygen measured with two- and onephoton excitation of $\mathrm{H}_{2} \mathrm{TMPyP}^{4+}$ photosensitizer for the sample prepared in $\mathrm{D}_{2} \mathrm{O}$. For one-photon excitation we used nonlinear crystal for generation of the second harmonic of Ti:sapphire laser at $390 \mathrm{~nm}$. In this experiment the intensity of ${ }^{1} \Delta_{g} \rightarrow{ }^{3} \Sigma_{g}^{-}$luminescence

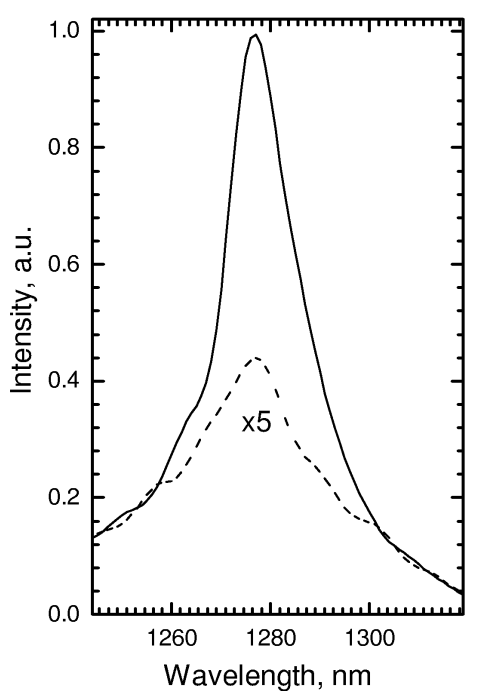

Fig. 4. ${ }^{1} \Delta_{g} \rightarrow{ }^{3} \Sigma_{g}^{-}$luminescence spectra of molecular oxygen in air-equilibrated heavy water solution of $\mathrm{H}_{2} \mathrm{TMPyP}^{4+}$ porphyrin. Dashed and solid curves represent, respectively, the spectra measured with two- and one-photon excitation.

signal increased linearly with laser power. Two-photon excitation of $\mathrm{H}_{2} \mathrm{TMPyP}^{4+}$ porphyrin in these experiments with ${ }^{1} \Delta_{g}$ photosensitization has been done at $780 \mathrm{~nm}$. At this wavelength sensitizer has a moderate two-photon absorption cross-section $\sigma_{\mathrm{TPA}}=85 \mathrm{GM}$, whereas $\sigma_{\text {TPA }}$ value growths up to $180 \mathrm{GM}$ when the excitation wavelength is shifted to $735 \mathrm{~nm}$. We used the following arguments to make a wavelength choice in such a way. Firstly, the excitation wavelength should fall in the tissue transparency window. Secondly, it was desirable to measure the ${ }^{1} \Delta_{g}$ oxygen photosensitization upon excitation with commercially available laser system. $\lambda=780 \mathrm{~nm}$ is the operating wavelength of the commercial Ti:sapphire laser and it meets both above requirements. Both ${ }^{1} \Delta_{g} \rightarrow{ }^{3} \Sigma_{g}^{-}$luminescence spectra measured with one- and two-photon excitation have the same shape and the maximum position at $1276 \pm 1 \mathrm{~nm}$. This finding is in agreement with literature data for one-photon excitation [36]. The luminescence intensities of the same order of magnitude have been found in two cases, when the average laser power was $15 \mathrm{~W} / \mathrm{cm}^{2}$ and $0.5 \mathrm{~W} / \mathrm{cm}^{2}$ for two- and one-photon excitation, respectively.

Fluence rate of $15 \mathrm{~W} / \mathrm{cm}^{2}$ is one order of magnitude higher than those used in PDT protocols [12], where it is varied from $100 \mathrm{~mW} / \mathrm{cm}^{2}$ for Foscan $\AA$ up to $1 \mathrm{~W} / \mathrm{cm}^{2}$ in case of Photosens $\AA$. Therefore, it is important to compare the former figure with that for tissue damage threshold to conclude if such a fluence rate can be used in clinical practice. Low absorption of the tissues in near-IR region greatly reduces potential 
for hyperthermal effects, and femtosecond duration of pulses prevents the initiation of collisional ionization and other avalanche damage mechanisms [15]. As a result, the irradiance from unfocused Ti:sapphire beam (as it was in our case) is found to be approximately six orders of magnitude below the tissue damage threshold [15]. This fact means that the photosensitization efficiency comparable with that found with one-photon excitation can by achieved with two-photon excitation of molecules having the $\sigma_{\mathrm{TPA}}$ value of about $100 \mathrm{GM}$ and higher at the fluence rate well below the tissue damage threshold.

The two-photon absorbance by living tissues has been shown to be negligibly small and not interfering with two-photon absorbance of photosensitizer embedded into living tissues $[15,17,18,37]$. It is known that focused ultrashort pulses suffer from spatial and temporal dispersion [38]. However, it has been shown experimentally that for laser pulses with halfwidth of 100-200 fs these effects are not substantial even in the living tissues for the experiments in vitro [37]. That is why it is possible to localize an excitation in the volume of order of few $\mu \mathrm{m}^{3}$ and to achieve efficient two-photon excitation. It is worthwhile to note that for next generation of TPE photosensitizers, having TPA cross-section of about several hundred GM, the excitation with picosecond lasers can be applied. Thus, the restrictions limiting an application of ultrashort laser pulses for two-photon excitation in biology can be successfully overpassed [37].

As we already have pointed out above, a major shortcoming of the porphyrins as photodynamic agents consists in their weak absorption in the red region of visible spectrum. For this reason, many of the known porphyrin sensitizers, even possessing a high yield of singlet oxygen photosensitization and meeting biological requirements of optimal balance between hydrophobic and hydrophilic properties, have been ruled out from potential candidates for PDT application. Out of the various possible ways to overcome the above limitation, simultaneous two-photon excitation seems to be a promising one (Fig. 5). We have to note once more that for centrosymmetric molecules (and for quasicentrosymmetric molecules, in fact) the selection rules for two-photon or one-photon absorption are alternative. Therefore the initial excited states populated in both cases are different. However, independently of excitation mechanism, the lowest exited triplet state, $\mathrm{T}_{1}$, is ultimately populated as a result of intramolecular radiationless transitions in porphyrin photosensitizer [13]. Hence, provided that high

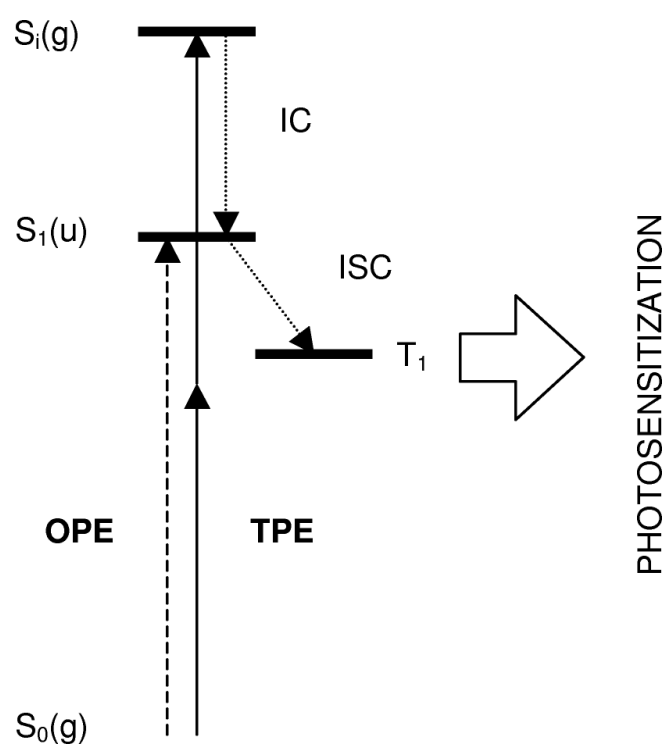

Fig. 5. Sketch of the energy levels for porphyrin photosensitizer. $\mathrm{S}_{0}(g), \mathrm{S}_{1}(u), \mathrm{S}_{i}(g)$, and $\mathrm{T}_{1}$ represent, respectively, the ground, first singlet, $i$ th excited singlet, and lowest triplet states of the photosensitizer. The symbols in the parentheses denote gerade $(g)$ and ungerade $(u)$ symmetry of the corresponding states. Upon onephoton excitation (OPE), the lowest singlet state $S_{1}$ of photosensitizer is populated. Upon two-photon excitation (TPE), a transition occurs to one of the higher excited states $S_{i}(g)$. In this case the energy of the excitation photon is much lower than that used in OPE and falls into the tissue transparency window. Because of the internal conversion (IC) and intersystem crossing (ISC) the $\mathrm{T}_{1}$ state is ultimately populated. This is followed by energy transfer from photosensitizer to the ground state oxygen, resulting in the singlet oxygen photosensitized formation: $\mathrm{T}_{1}+{ }^{3} \Sigma_{g}^{-} \rightarrow \mathrm{S}_{0}+{ }^{1} \Delta_{g}$.

efficiency of two-photon excitation is accomplished, the pronounced photodynamic effect can be obtained. This two-photon excitation scheme, which we first proposed in Ref. [21], differs from those suggested earlier $[13,15]$ in that we have proposed to excite the photosensitizer into one of the higher excited $\mathrm{S}_{i}$ states (actually, for free base porphyrins it is higher than $S_{4}$ state), whereas in earlier schemes $S_{1}$ state has been proposed. Because of the alternative selection rules the $\sigma_{\text {TPA }}$ value for two-photon excitation of porphyrins into $S_{1}$ state is too low to have any practical application (see Fig. 3(b)), whereas two-photon allowed $g \rightarrow g$ transition has high $\sigma_{\text {TPA }}$ value (Fig. 3(a)). Our results prove that efficient two-photon excitation can be achieved for water-soluble $\mathrm{H}_{2} \mathrm{TMPyP}^{4+}$ porphyrin (TPA crosssection $\sigma_{\mathrm{TPA}}=85 \mathrm{GM}$ at the excitation wavelength), giving rise to an observable ${ }^{1} \Delta_{g}$ singlet oxygen photosensitization. Thus, from the point of view of twophoton absorptivity the meso-tetrapyridyl-substituted porphyrins seem to have the advantages over their meso-tetraphenyl-substituted counterparts $\left(\mathrm{H}_{2} \mathrm{TSPP}^{4-}\right.$ porphyrin has $\sigma_{\mathrm{TPA}}=21 \mathrm{GM}$ at $780 \mathrm{~nm}$ ). 


\section{Conclusions}

The experimental data reported in this paper prove a new excitation scheme for porphyrin photosensitizers based on simultaneous two-photon absorption in the $g \rightarrow g$ transitions. This approach seems to be of importance in PDT because it does not require strong absorption by porphyrin photosensitizer at the red edge of visible spectrum and allows considering many porphyrin molecules, which reveal photodynamic activity in vitro, as potential drugs for PDT. Owing to reduced absorption and scattering of IR light this excitation scheme can provide a greater depth of penetration into biological tissues, high spatial localization of excitation, and can minimize the laser-induced hyperthermia [37]. Our observations open the perspective to increase the potential of well-studied porphyrin photosensitizers in photodynamic therapy.

\section{Acknowledgements}

The authors thank Prof. Rufus Cone (Montana State University) for loaning the IR-detector for singlet oxygen luminescence measurements. This work was supported by AFOSR grant F49620-01-1-0324.

\section{References}

[1] J.C. Howard, E.H. Mark, and N. Datta-Gupta, Interaction of DNA with a porphyrin ligand: Evidence for intercalation, Nucleic Acids Res. 6(9), 3093-3120 (1979).

[2] R.J. Fiel, N. Datta-Gupta, E.H. Mark, and J.C. Howard, Induction of DNA damage by porphyrin photosensitizers, Cancer Res. 41, 3543-3545 (1981).

[3] J.-B. Verlhac, A. Gaudemer, and I. Kraljic, Watersoluble porphyrins and metalloporphyrins as photosensitizers in aerated aqueous solutions. I. Detection and determination of quantum yield of formation of singlet oxygen, Nouv. J. Chim. 8(6), 401-406 (1984).

[4] D. Praseuth, A. Gaudemer, J.-B. Verlhac, I. Kraljic, I. Sissoeff, and E. Guie, Photocleavage of DNA in the presence of synthetic water-soluble porphyrins, Photochem. Photobiol. 44(6), 717-724 (1986).

[5] V.S. Chirvony, V.A. Galievsky, N.N. Kruk, B.M. Dzhagarov, and P.-Y. Turpin, Photophysics of the cationic 5, 10, 15, 20-tetrakis(4-N-methylpyridyl) porphyrin bound to DNA, [poly $(\mathrm{dG}-\mathrm{dC})]_{2}$ and $[$ poly $(\mathrm{dA}-$ $\mathrm{dT})]_{2}$ : On a possible charge transfer process between guanine and porphyrin in its excited singlet state, J. Photochem. Photobiol. B 40(2), 154-162 (1997).

[6] N.N. Kruk, B.M. Dzhagarov, V.A. Galievsky, V.S. Chirvony, and P.-Y. Turpin, Photophysics of the cationic 5, 10,15,20-tetrakis(4-N-methylpyridyl) porphyrin bound to DNA, [poly $(\mathrm{dG}-\mathrm{dC})]]_{2}$ and $[\text { poly }(\mathrm{dA}-\mathrm{dT})]_{2}$ : Interaction with molecular oxygen studied by porphyrin triplet-triplet absorption and singlet oxygen luminescence, J. Photochem. Photobiol. B 42(3), 181-190 (1998).

[7] N.N. Kruk, S.I. Shishporenok, A.A. Korotky, V.A. Galievsky, V.S. Chirvony, and P.-Y. Turpin, Binding of the cationic 5,10,15,20-tetrakis(4-Nmethylpyridyl) porphyrin bound at 5'CG3' and 5'GC3' sequences of hexadeoxyribonucleotides: Triplet-triplet transient absorption, steady-state and time-resolved fluorescence and resonance Raman studies, J. Photochem. Photobiol. B 45(1), 67-74 (1998).

[8] M. Merchat, J.D. Spikes, G. Bertoloni, and G. Jori, Studies on the mechanism of bacteria photosensitization by meso-substituted cationic porphyrins, J. Photochem. Photobiol. B, 35(2), 149-157 (1996).

[9] N.N. Kruk and A.A. Korotkii, Photophysical properties and photoreduction of 5,10, 15, 20-tetrakis-(4$\mathrm{N}$-methylpyridyl) porphyrin in formamide, J. Appl. Spectr. (translated from Russian) 67(6), 966-971 (2000).

[10] San Wan, J. Parrish, R. Rox Anderson, and M. Madden, Transmittance of nonionizing radiation in human tissues, Photochem. Photobiol. 34(6), 679-681 (1981).

[11] R. Bonnett, Photosensitizers of the porphyrin and phthalocyanine series for photodynamic therapy, Chem. Soc. Rev. 24, 19-33 (1995).

[12] R. Bonnett, Chemical Aspects of Photodynamic Therapy (Gordon and Breach, Amsterdam, 2000).

[13] W.G. Fisher, W.P. Partridge, Jr., C. Dees, and E.A. Wachter, Simultaneous two-photon activation of type-I photodynamic therapy agents, Photochem. Photobiol. 66(2), 141-155 (1997).

[14] D. Leupold and I.E. Kochevar, Multiphoton photochemistry in biological systems. Introduction, Photochem. Photobiol. 66(5), 562-565 (1997).

[15] E.A. Wachter, W.P. Partridge, W.G. Fisher, H.C. Dees, and M.G. Petersen, Simultaneous two-photon excitation of photodynamic therapy agents, Proc. SPIE - Int. Soc. Opt. Eng. 3269, 68-74 (1998).

[16] M. Göppert-Mayer, Elementartakte mit zwei Quantensprüngen, Ann. Phys. 9, 273-294 (1931).

[17] L. Kelbauskas and W. Dietel, Internalization of aggregated photosensitizers by tumor cells: Subcellular time-resolved fluorescence spectroscopy on derivatives of pyropheophorbide-a ethers and chlorin $\mathrm{e}_{6}$ under femtosecond one- and two-photon excitation, Photochem. Photobiol. 76(6), 686-694 (2002).

[18] C. Xu, W. Zipfel, J.B. Shear, R.M. Williams, and W.W. Webb, Multiphoton fluorescence excitation: New spectral windows for biological nonlinear microscopy, Proc. Natl. Acad. Sci. USA 93, $10763-$ 10768 (1996). 
[19] N.N. Vsevolodov, L.P. Kostikov, L.P. Kayushin, and V.I. Gorbatenkov, Two-photon absorption of laser emission by chlorophyll $a$ and several organic dyes, Biofizika 18, 755-757 (1973) [in Russian].

[20] R.L. Goyan and D.T. Gramb, Near-infrared twophoton excitation of protoporphyrin IX: Photodynamic and photoproduct generation, Photochem. Photobiol. 72(6), 821-827 (2000).

[21] A. Karotki, M. Kruk, M. Drobizhev, A. Rebane, E. Nickel, and C.W. Spangler, Efficient singlet oxygen generation upon two-photon excitation of new porphyrin with enhanced nonlinear absorption, IEEE J. Sel. Topics Quantum Electron. 7(6), 971-975 (2001).

[22] M. Drobizhev, A. Karotki, M. Kruk, and A. Rebane, Resonance enhancement of two-photon absorption in porphyrins, Chem. Phys. Lett. 355(1-2), 175182 (2002).

[23] M. Drobizhev, A. Karotki, M. Kruk, N.Zh. Mamardashvili, and A. Rebane, Drastic enhancement of twophoton absorption in porphyrins associated with symmetrical electron-accepting substitution, Chem. Phys. Lett. 361(5-6), 504-512 (2002).

[24] A. Karotki, M. Drobizhev, M. Kruk, C.W. Spangler, E. Nickel, N. Mamardashvili, and A. Rebane, Enhancement of two-photon absorption in tetrapyrrolic compounds, J. Opt. Soc. Am. B 20(2), 321-332 (2003).

[25] M. Kruk, A. Karotki, M. Drobizhev, and A. Rebane, First observation of two-photon photosensitization of singlet molecular oxygen by porphyrin in aqueous solution, in: Digest of LALS-IX Conference (Vilnius, Lithuania, July 2002), 92 (2002).

[26] A. Karotki, M. Drobizhev, M. Kruk, A. Rebane, E. Nickel, and C.W. Spangler, Strong two-photon absorption and singlet oxygen photogeneration in near-IR with new porphyrin molecule, Proc. SPIE - Int. Soc. Opt. Eng. 4612, 143-151 (2002).

[27] V.A. Kuz'mitskii, Excited even-symmetry states of metallocomplexes of porphin and its derivatives, J. Appl. Spectrosc. (translated from Russian) 68(5), 758-765 (2001) .
[28] R.F. Pasternack, E.J. Gibbs, and J.J. Villafranca, Interaction of porphyrins with nucleic acids, Biochemistry 22(10), 2406-2414 (1983).

[29] M.D. Galanin and Z.A. Chizhikova, Effective TPA cross-sections in organic molecules, Pis'ma Zh. Eksp. Teor. Fiz. [JETP Letters] 4(2), 41-43 (1966) [in Russian].

[30] F. Wilkinson, W.P. Helman, and A.B. Ross, Rate constant for the decay and reactions of the lowest electronically excited singlet state of molecular oxygen in solution. An expanded and revised compilation, J. Phys. Chem. Ref. Data 24(2), 663-1021 (1995).

[31] F.J. Vergeldt, R.B.M. Koehorst, A. Van Hoek, and T. Schaafsma, Intramolecular interactions in the ground and excited state of tetrakis(N-methylpyridyl) porphyrins, J. Phys. Chem. 99(13), 4397-4405 (1995).

[32] N.N. Kruk, O.P. Parkhots, and N.V. Ivashin, Spectral manifestation of anion-cation interactions of watersoluble porphyrins, J. Appl. Spectrosc. (translated from Russian) 68(6), 924-929 (2001).

[33] T. Gensch, C. Viappiani, and S.E. Braslavsky, Structural volume changes upon photoexcitation of porphyrins: Role of the nitrogen-water interactions, J. Am. Chem. Soc. 121(45), 10573-10582 (1999).

[34] A.A. Krasnovsky, Jr., S.Yu. Egorov, O.V. Nazarova, E.V. Yartsev, and G.V. Ponomarev, Photogeneration of singlet molecular oxygen by water-soluble porphyrins, Biofizika 32(6), 982-993 (1982) [in Russian].

[35] N.G. Angeli, M. Gabriela Lagorio, E.A. San Roman, and L.E. Dicello, Meso-substituted cationic porphyrins of biological interest. Photophysical and physicochemical properties in solution and bound to liposomes, Photochem. Photobiol. 72(1), 49-56 (2000).

[36] R. Schmidt, Solvent shift of the ${ }^{1} \Delta_{g} \rightarrow{ }^{3} \Sigma_{g}^{-}$phosphorescence of $\mathrm{O}_{2}$, J. Phys. Chem. 100(20), 8049-8052 (1996).

[37] R. Zipfel, R.M. Williams, and W.W. Webb, Nonlinear magic: Multiphoton microscopy in the bioscience, Nature Biotechnology 21(11), 1369-1377 (2003).

[38] R.W. Boyd, Nonlinear Optics (Academic Press, San Diego, 2003). 


\title{
SINGULETINIO MOLEKULINIO DEGUONIES FOTOJAUTRINIMAS, DVIFOTONIŠKAI ŽADINANT PORFIRINA VANDENS TIRPALE
}

\author{
M. Kruk ${ }^{a, b}$, A. Karotki ${ }^{\text {b,c }}$, M. Drobizhev ${ }^{b}$, A. Rebane ${ }^{\text {b }}$ \\ ${ }^{a}$ Nacionalinès mokslu akademijos Molekulinès ir atominès fizikos institutas, Minskas, Baltarusija \\ ${ }^{\mathrm{b}}$ Montanos valstijos universitetas, Bozemanas, JAV \\ ${ }^{\mathrm{c}}$ Ontario véžio institutas, Torontas, Kanada
}

\section{Santrauka}

Gerai žinomas vandenyje tirpaus porfirino fotodinaminis aktyvumas. Tačiau porfirinu fotojautrinanti panaudojima fotodinamineje terapijoje riboja nepakankama sugertis raudonajame spektro ruože, kuriame kūno audiniai nesugeria spinduliuotès. Šių molekulių dvifotonis sužadinimas (DFS) padeda išvengti šio apribojimo. Lig šiol DFS buvo laikomas neefektyviu ir neturinčiu praktinès vertès. Šiame darbe dvifotonè savitoji sugertis ir singuletinio deguonies fotojautrinimas 5,10,15,20-tetrakis-(4-Nmetilpiridil)-21H,23H-porfirinu vandens tirpale buvo tiesiogiai patikrinti. Dvifotonès sugerties skerspjūvio $\sigma_{\mathrm{DFS}}$ didumas kinta nuo 60 ligi $180 \mathrm{GM}$, derinant sužadinimo bangos ilgi nuo 800 iki
730 nm. Atrasta, kad mèlynajame Soret'o juostos (B juosta) krašte ši sugertis pasireiškia dèl dvifotonès leistino šuolio sugerties i lyginio lygiškumo būseną ( $g \rightarrow g$ šuolis). DFS i Q būsenas yra uždraustas pagal lygiškumą ( $g \rightarrow u$ šuolis) ir $\sigma_{\text {DFS }}$ didumas neviršija 6 GM 1100-1400 nm spektro ruože. Porfirino DFS ties $780 \mathrm{~nm}$ oro prisotintame sunkiojo vandens tirpale efektyviai jautrina singuletinį molekulinį deguoni $\left({ }^{1} \Delta_{g}\right)$, kuris detektuojamas per ${ }^{1} \Delta_{g} \rightarrow{ }^{3} \Sigma_{g}$ liuminescenciją. Mūsų išaiškinimais parodytas dvifotonio sužadinimo tinkamumas fotodinaminei terapijai ir galimybė nustatyti reikalavimus panaudojamos fotojautrinančios medžiagos dvifotonei savitajai sugerčiai. 